\title{
Crystallization in Pd40Ni40P20 glass
}

\author{
Jiang, Jianzhong; SaksI, K.; Nishiyama, N.; Inoue, A.
}

\section{Published in:}

Journal of Applied Physics

Link to article, DOI:

$10.1063 / 1.1505681$

Publication date:

2002

Document Version

Publisher's PDF, also known as Version of record

Link back to DTU Orbit

Citation (APA):

Jiang, J., Saksl, K., Nishiyama, N., \& Inoue, A. (2002). Crystallization in Pd40Ni40P20 glass. Journal of Applied Physics, 92(7), 3651-3656. https://doi.org/10.1063/1.1505681

\section{General rights}

Copyright and moral rights for the publications made accessible in the public portal are retained by the authors and/or other copyright owners and it is a condition of accessing publications that users recognise and abide by the legal requirements associated with these rights.

- Users may download and print one copy of any publication from the public portal for the purpose of private study or research.

- You may not further distribute the material or use it for any profit-making activity or commercial gain

- You may freely distribute the URL identifying the publication in the public portal

If you believe that this document breaches copyright please contact us providing details, and we will remove access to the work immediately and investigate your claim. 


\title{
Crystallization in $\mathrm{Pd}_{40} \mathrm{Ni}_{40} \mathrm{P}_{20}$ glass
}

\author{
J. Z. Jiang ${ }^{\text {a) }}$ and K. Saksl \\ Department of Physics, Building 307, Technical University of Denmark, DK-2800 Lyngby, Denmark
}

N. Nishiyama

Inoue Superliquid Glass Project, ERATO, Japan Science and Technology Corporation (JST), Sendai 982-0807, Japan

A. Inoue

Institute for Materials Research, Tohoku University, Sendai 980-8577, Japan

(Received 20 February 2002; accepted for publication 11 July 2002)

Phase segregation and the effect of pressure on crystallization of bulk and ribbon $\operatorname{Pd}_{40} \mathrm{Ni}_{40} \mathrm{P}_{20}$ glasses have been studied by means of differential scanning calorimetry (DSC) and x-ray diffraction. The DSC measurements show only one glass transition event in the samples annealed at different temperatures in the supercooled liquid region. Phase analyses reveal at least five crystalline phases crystallized from the glass: monoclinic; body-centered tetragonal; orthorhombic; $\mathrm{Ni}_{2} \mathrm{Pd}_{2} \mathrm{P}$ and fcc-(Ni,Pd) solid solution phases. In the pressure range from 0 to $4.2 \mathrm{GPa}$, the crystallization temperature increases with pressure having a slope of $11 \mathrm{~K} / \mathrm{GPa}$. The eutectic crystallization reaction mode and crystalline phases formed are unchanged in the pressure range used. The enhancement of the crystallization temperature with increasing pressure in the glass can be explained by the suppression of atomic mobility. (C) 2002 American Institute of Physics.

[DOI: $10.1063 / 1.1505681]$

\section{INTRODUCTION}

Many metallic melts can be configurationally frozen to the amorphous phase, provided they can be cooled at a sufficient high rate to avoid crystal nucleation and growth. The discovery of several families of multicomponent alloys exhibiting a large supercooled liquid region before crystallization, such as La- (Ref. 1) and Zr- (Refs. 2 and 3) based alloys, has triggered tremendous research activity in this field (bulk metallic glasses). ${ }^{4,5}$ These novel materials possess an extremely high glass forming ability and high thermal stability against crystallization. In fact, $\mathrm{Pd}_{40} \mathrm{Ni}_{40} \mathrm{P}_{20}$ was discovered as the first bulk metallic glass forming alloy ${ }^{6}$ with a critical cooling rate as low as about $1 \mathrm{~K} / \mathrm{s}$ when processed in $\mathrm{B}_{2} \mathrm{O}_{3},{ }^{7}$ and a high reduced glass transition temperature $T_{r g}$ $=0.66^{8}$ (defined as $T_{r g}=T_{g} / T_{m}$, where $T_{g}$ and $T_{m}$ are the glass transition and melting temperature, respectively). The formation, structure, and thermal stability of Pd-Ni-P glasses have been intensively investigated. ${ }^{6-45}$ The issue of phase segregation in Pd-Ni-P glasses annealed in the supercooled liquid region, prior to the onset of crystallization, still remains debated. Chen ${ }^{11}$ first reported double-glass transitions in $\left(\mathrm{Pd}_{5} \mathrm{Ni}_{5}\right)_{1-x} \mathrm{P}_{x}(x=0.19$ and 0.18$)$ glassy ribbons annealed to the end of the first exothermic peak. Phase separation before crystallization was proposed in Pd-Ni-P glassy ribbons with $\mathrm{P}$ content less than 20 at. $\%{ }^{13}$ Further investigations, e.g., by atom probe field ion microscopy (APFIM) for $\mathrm{Pd}_{35} \mathrm{Ni}_{45} \mathrm{P}_{20}$ (Ref. 15) and $\mathrm{Pd}_{36} \mathrm{Ni}_{47} \mathrm{P}_{17}$ (Ref. 25) ribbons, by differential scanning calorimetry (DSC) for $\mathrm{Pd}_{25} \mathrm{Ni}_{58} \mathrm{P}_{17},{ }^{17} \mathrm{Pd}_{40} \mathrm{Ni}_{40} \mathrm{P}_{20},{ }^{20}$ and $\mathrm{Pd}_{41} \mathrm{Ni}_{41} \mathrm{P}_{18}$ (Ref. 23) rib-

a) Author to whom correspondence should be addressed: electronic mail: jiang@fysik.dtu.dk bons, by x-ray diffraction (XRD) and transmission electron microscopy for a $\mathrm{Pd}_{41} \mathrm{Ni}_{41} \mathrm{P}_{18}$ ribbon, ${ }^{23}$ also suggested phase separation prior to crystallization in the supercooled liquid region of Pd-Ni-P alloys. On the other hand, small-angle X-ray scattering investigations of $\mathrm{Pd}_{46} \mathrm{Ni}_{36} \mathrm{P}_{18},{ }^{24}$ APFIM studies of $\mathrm{Pd}_{31} \mathrm{Ni}_{45} \mathrm{P}_{24},{ }^{25} \mathrm{Pd}_{50} \mathrm{Ni}_{30} \mathrm{P}_{20},{ }^{25} \mathrm{Pd}_{46} \mathrm{Ni}_{36} \mathrm{P}_{18},{ }^{37}$ and $\mathrm{Pd}_{48} \mathrm{Ni}_{32} \mathrm{P}_{20}$ (Ref. 37) glassy ribbons did not reveal phase separation in the samples annealed in the supercooled liquid region. Read et al. ${ }^{37}$ further investigated glassy $\mathrm{Pd}_{46} \mathrm{Ni}_{36} \mathrm{P}_{18}$ and $\mathrm{Pd}_{48} \mathrm{Ni}_{32} \mathrm{P}_{20}$ wires $(\approx 100 \mu \mathrm{m})$, prepared by rotatingwater melt spinning, APFIM, and high-resolution electron microscopy and found no phase separation in the samples annealed in the supercooled liquid region. Recently, Miller et al. ${ }^{40}$ reexamined the phase separation phenomenon in a $\mathrm{Pd}_{40} \mathrm{Ni}_{40} \mathrm{P}_{20}$ bulk glassy rod ( $7 \mathrm{~mm}$ in diameter), prepared by aflux and water quenching technique, by means of APFIM. Phase separation was observed in the bulk glass annealed above the glass transition temperature. This conclusion was also supported by the observation of triple glass transitions in DSC for a $\mathrm{Pd}_{40.5} \mathrm{Ni}_{40.5} \mathrm{P}_{19}$ bulk glassy rod $(6 \mathrm{~mm}$ in diameter), prepared by aflux and air quenching technique, after annealing in the supercooled liquid region. ${ }^{44}$ In this work, we perform detailed DSC measurements on both as-prepared bulk and ribbon $\mathrm{Pd}_{40} \mathrm{Ni}_{40} \mathrm{P}_{20}$ glasses and the samples annealed in the supercooled liquid region. The difference of the relative amounts of various crystalline phases in the samples annealed under three pressures of $10^{-5} \mathrm{mbar}, 1 \mathrm{bar}$, and 6 kbar is presented. Furthermore, crystallization of the $\mathrm{Pd}_{40} \mathrm{Ni}_{40} \mathrm{P}_{20}$ glass under pressure has been investigated by in situ high-temperature and high-pressure (0-4.2 GPa) XRD measurements using synchrotron radiation. We found that (1) the eutectic crystallization reaction mode and crystalline 
phases formed are unchanged in the pressure range used and (2) crystallization temperature increases with pressure, having a rate of $11 \mathrm{~K} / \mathrm{GPa}$.

\section{EXPERIMENTAL PROCEDURE}

The master alloy ingot was prepared by arc melting, a mixture of $\mathrm{Pd}(99.9 \mathrm{wt} \%)$ and $\mathrm{Ni}_{2} \mathrm{P}$ in the right proportion, together with $\mathrm{B}_{2} \mathrm{O}_{3}$ flux medium in purified argon atmosphere. $\mathrm{B}_{2} \mathrm{O}_{3}$ flux was used in order to enhance the large glass forming ability of the alloy by eliminating heterogeneous nuclei. A glassy rod-shaped sample (hereafter called the bulk) with a diameter of $3 \mathrm{~mm}$ was prepared by the water quenching method described in Ref. 46. A glassy ribbon (hereafter called the ribbon) with a cross section of $0.02 \mathrm{~mm} \times 1 \mathrm{~mm}$ was produced by a single-roller meltspinning method from the same master ingot in an argon gas atmosphere. The formation of a single glassy phase in both bulk and ribbon samples was confirmed by XRD and transmission electron microscopy measurements. Thermal analyses were performed in a Perkin Elmer Differential Scanning Calorimeter DSC 7 at a heating rate $20 \mathrm{~K} / \mathrm{min}$ under a flow of purified argon. Some samples were first heated in the DSC at the rate of $20 \mathrm{~K} / \mathrm{min}$ to a given temperature, then kept at the temperature for $30 \mathrm{~min}$, and finally cooled at the rate of $100 \mathrm{~K} / \mathrm{min}$ to $300 \mathrm{~K}$. Some samples were annealed in vacuum or $\mathrm{Ar}$ atmosphere using a silica tube. The XRD patterns were recorded using a Philips PW 1820 diffractometer with $\mathrm{Cu} K \alpha$ radiation. In situ high-pressure and hightemperature energy-dispersive $\mathrm{x}$-ray diffraction (EDXRD) measurements were performed using synchrotron radiation at HASYLAB in Hamburg, Germany, and a multianvil pressure apparatus with $8 \mathrm{~mm}$ cube pressure cells. ${ }^{47}$ The cubic sample assembly is compressed by six truncation anvils of tungsten carbide in a 250 ton hydraulic press. Electric current is sent through a graphite heater via two appropriate anvils. The temperature is measured by means of thermocouple voltage with a stability of $\pm 1 \mathrm{~K}$. Each run consists of an isothermal room-temperature compression followed by an isobaric heating to high temperature in steps of $10 \mathrm{~K}$. The average heating rate in the temperature range from 298 to $800 \mathrm{~K}$ was roughly estimated to be $3 \mathrm{~K} / \mathrm{min}$. The pressure of the sample is calculated from the lattice constant of $\mathrm{NaCl}$ using the Decker equation of state. ${ }^{48}$ Pure $\mathrm{Zr}, \mathrm{Fe}$, and the bulk metallic glass powders were used to examine the possible oxidation of samples during the heat treatments using the sample assembly. It was found that only pure metallic phases in the three systems were detected after heat treatments at temperatures up to $800 \mathrm{~K}$.

\section{RESULTS AND DISCUSSION}

Figures 1 and 2 show the DSC traces of the as-prepared ribbon and bulk $\mathrm{Pd}_{40} \mathrm{Ni}_{40} \mathrm{P}_{20}$ glasses and the samples annealed in the DSC at different temperatures in the supercooled liquid region for $30 \mathrm{~min}$, respectively. Both asprepared samples exhibit an endothermic event characteristic of the glass transition $\left(T_{g}=575 \mathrm{~K}\right.$ for the ribbon and $T_{g}$ $=579 \mathrm{~K}$ for the bulk), followed by one exothermic event indicating a eutectic crystallization process. The onset tem-

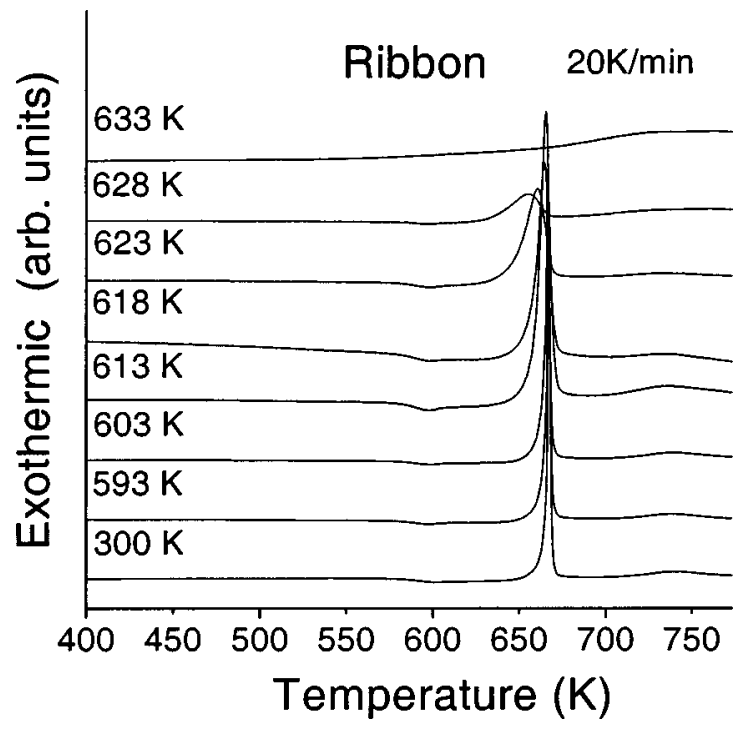

FIG. 1. The DSC traces of the as-prepared $\mathrm{Pd}_{40} \mathrm{Ni}_{40} \mathrm{P}_{20}$ ribbon glass and the samples annealed at different temperatures in the supercooled liquid region for $30 \mathrm{~min}$, at a heating rate of $20 \mathrm{~K} / \mathrm{min}$ under a flow of purified argon.

perature of the crystallization reaction of the ribbon is $T_{x}^{\text {onset }}=665 \mathrm{~K}$ and of the bulk $T_{x}^{\text {onset }}=671 \mathrm{~K}$. These data agree well with the data reported in the literature for this alloy. All parameters, $T_{g}, T_{x}^{\text {onset }}$, and heat of crystallization $\Delta H_{x}$, deduced from DSC measurements are plotted in Figs. 3 and 4. $T_{g}$ remains almost constant for all the preannealing temperatures used and only one glass transition event was detected for both the annealed ribbon and bulk glasses. When the annealing temperature increases, the exothermic peak becomes broadened, while at $633 \mathrm{~K}$ it is very small, almost disappearing for the ribbon sample. These results are also reflected in the preannealing temperature dependences of $T_{x}^{\text {onset }}$ and $\Delta H_{x}$. Both ribbon and bulk $\mathrm{Pd}_{40} \mathrm{Ni}_{40} \mathrm{P}_{20}$ samples, annealed at various temperatures in the supercooled liquid region, show no multiglass transition events. A weak exo-

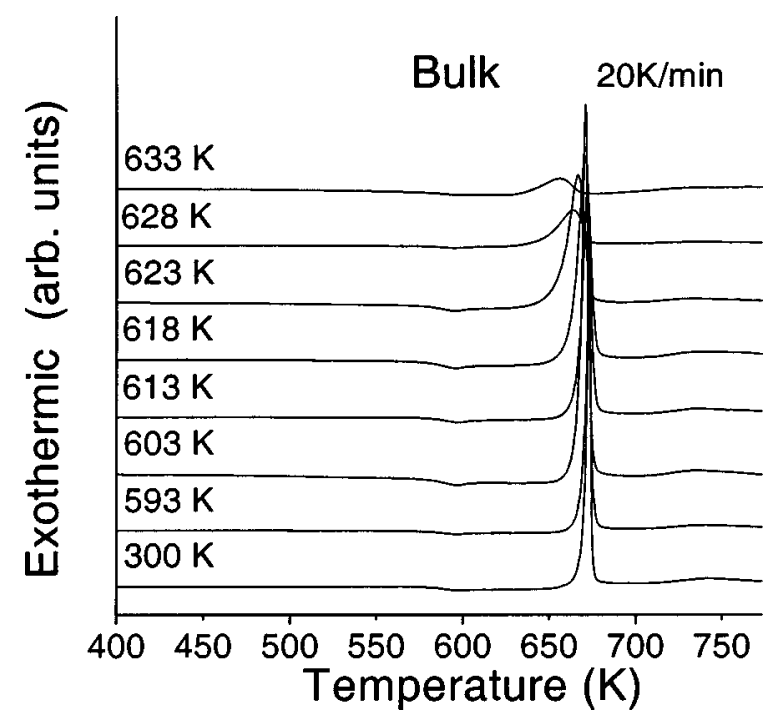

FIG. 2. The DSC traces of the as-prepared $\mathrm{Pd}_{40} \mathrm{Ni}_{40} \mathrm{P}_{20}$ bulk glass and the samples annealed at different temperatures in the supercooled liquid region for $30 \mathrm{~min}$, at a heating rate of $20 \mathrm{~K} / \mathrm{min}$ under a flow of purified argon. 


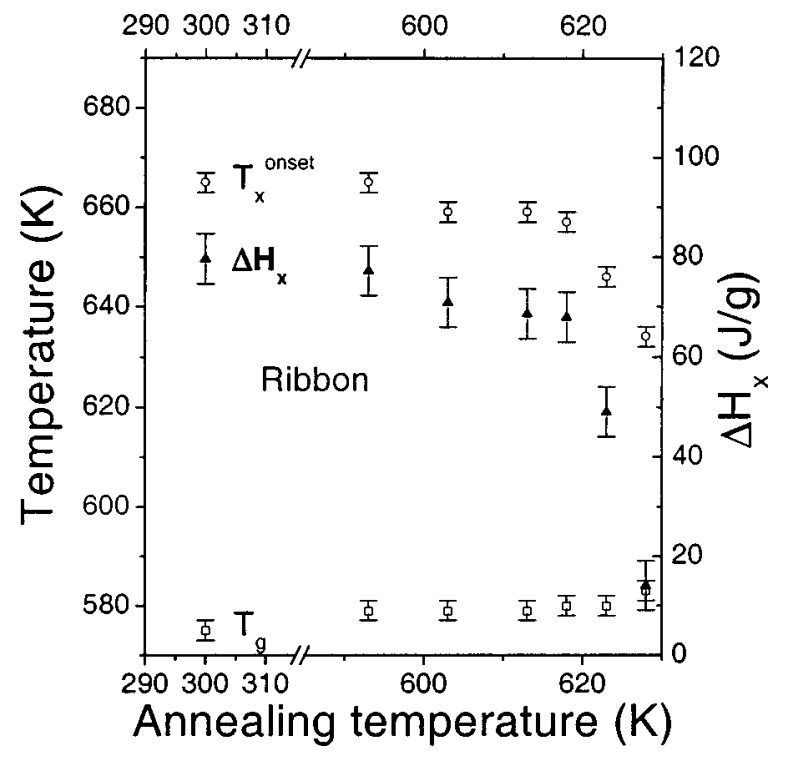

FIG. 3. The glass transition temperature $T_{g}$, the onset temperature of crystallization $T_{x}^{\text {onset }}$, and the heat of crystallization $\Delta H_{x}$ of the $\mathrm{Pd}_{40} \mathrm{Ni}_{40} \mathrm{P}_{20}$ ribbon glass as a function of annealing temperature.

thermic "bump" located at $740 \mathrm{~K}$ was also detected. To check whether the amorphous-to-crystalline phase transformation was complete after the first exothermic peak at around $670 \mathrm{~K}$, we further performed DSC measurements for both ribbon and bulk samples annealed in the DSC at $700 \mathrm{~K}$ for $30 \mathrm{~min}$. The DSC curves are flat, indicating that the amorphous-to-crystalline phase transformation is already complete after the exothermic peak at $670 \mathrm{~K}$. This "bump" could be due to decomposition of metastable crystalline phases and/or rearrangement of atoms in the crystalline phases (details given below).

The decrease of $\Delta H_{x}$ obtained in Figs. 3 and 4 is caused by a partial crystallization of the samples, which is con-

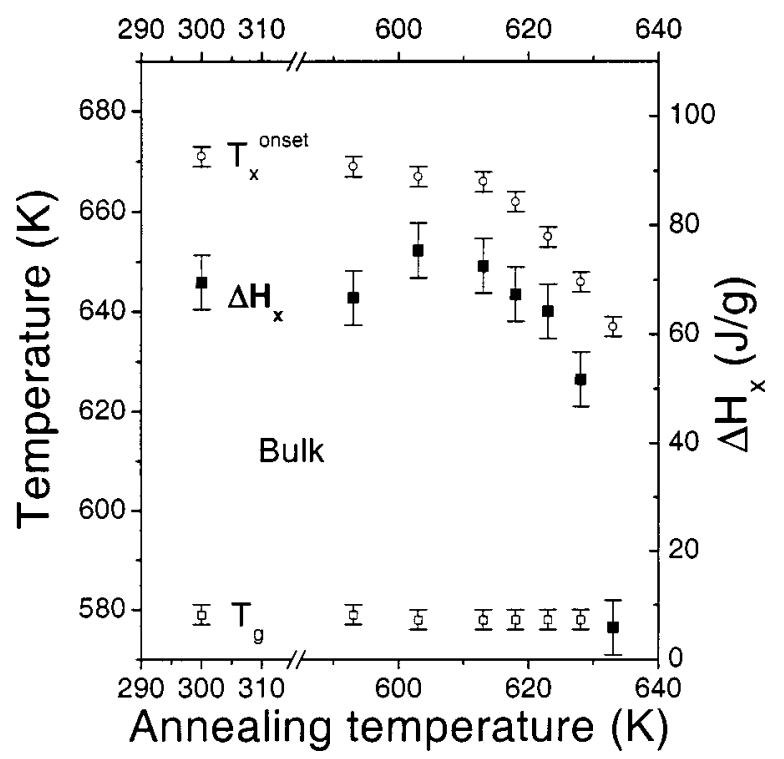

FIG. 4. The glass transition temperature $T_{g}$, the onset temperature of crystallization $T_{x}^{\text {onset }}$, and the heat of crystallization $\Delta H_{x}$ of the $\mathrm{Pd}_{40} \mathrm{Ni}_{40} \mathrm{P}_{20}$ bulk glass as a function of annealing temperature.

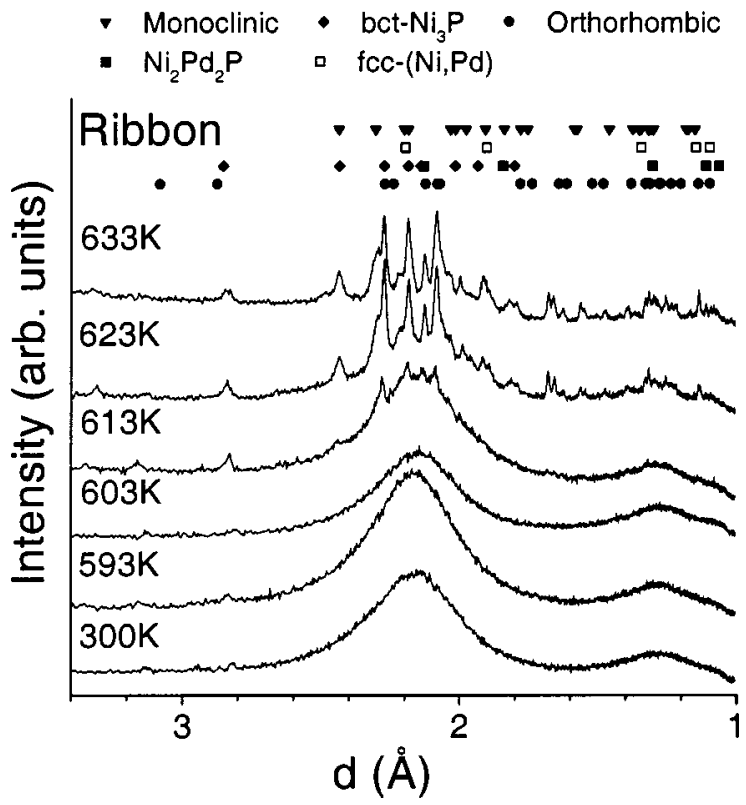

FIG. 5. X-ray diffraction patterns recorded at $295 \mathrm{~K}$ with $\mathrm{Cu} K \alpha$ radiation for the as-prepared $\mathrm{Pd}_{40} \mathrm{Ni}_{40} \mathrm{P}_{20}$ ribbon glass and the samples annealed at different temperatures in the supercooled liquid region for $30 \mathrm{~min}$.

firmed by XRD measurements of the corresponding samples in Figs. 5 and 6. XRD patterns recorded for ribbon and bulk samples annealed up to $603 \mathrm{~K}$ show a broad amorphous halo with a maximum around $2.18 \AA$ A. Samples annealed at $613 \mathrm{~K}$ are partially crystallized. It seems that the ribbon sample is more crystallized than the bulk sample. XRD patterns recorded from the samples annealed at 623 and $633 \mathrm{~K}$ exhibit an increase of crystalline component at the expense of the amorphous component and are composed of at least five crystalline compounds: phase 1 , monoclinic structure; phase 2, body-centered tetragonal $\mathrm{Ni}_{3} \mathrm{P}$-like structure; phase 3,

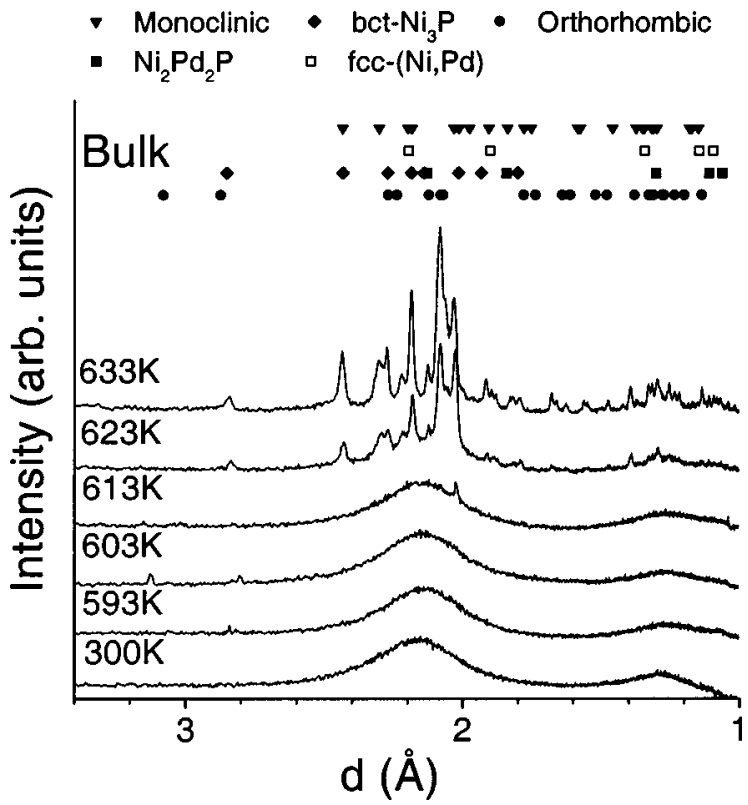

FIG. 6. X-ray diffraction patterns recorded at $295 \mathrm{~K}$ with $\mathrm{Cu} K \alpha$ radiation for the as-prepared $\mathrm{Pd}_{40} \mathrm{Ni}_{40} \mathrm{P}_{20}$ bulk glass and the samples annealed at different temperatures in the supercooled liquid region for $30 \mathrm{~min}$. 
TABLE I. Lattice parameters of the five crystalline phases: monoclinic, body-centered tetragonal (bct) $\mathrm{Ni}_{3} \mathrm{P}$-like, orthorhombic, fcc- $\mathrm{Ni}_{2} \mathrm{Pd}_{2} \mathrm{P}$, and fcc-(Ni,Pd) solid solution, obtained from the crystallized $\mathrm{Pd}_{40} \mathrm{Ni}_{40} \mathrm{P}_{20}$ alloy.

\begin{tabular}{clllrl}
\hline \hline & & \multicolumn{4}{c}{ Lattice parameters } \\
\cline { 3 - 6 } Phase & \multicolumn{1}{c}{ Structure } & $a(\AA)$ & $b(\AA)$ & $c(\AA)$ & $\beta\left({ }^{\circ}\right)$ \\
\hline 1 & monoclinic & 9.946 & 6.814 & 4.572 & 118.5 \\
2 & Bct-Ni ${ }_{3} \mathrm{P}-$ like & 2.969 & & 12.755 & \\
3 & orthorhombic & 8.285 & 7.982 & 3.648 & \\
4 & fcc-Ni ${ }_{2} \mathrm{Pd}_{2} \mathrm{P}$ & 3.69 & & & \\
5 & fcc- $(\mathrm{Ni}, \mathrm{Pd})$ & 3.89 & & & \\
\hline \hline
\end{tabular}

orthorhombic structure; phase $4, \mathrm{Ni}_{2} \mathrm{Pd}_{2} \mathrm{P}_{2}$ intermetallic compound; and phase 5 , fcc-(Ni,Pd) solid solution. The lattice parameters of the five phases are listed in Table I. Relatively strong diffraction peaks are indexed while some of the less intense peaks still remain unknown. The samples mainly consist of phases 1 and 2. The relative peak intensities are slightly different in ribbon and bulk samples. Donovan et al. ${ }^{16}$ performed x-ray microanalyses in transmission electron microscopy for a $\mathrm{Pd}_{40} \mathrm{Ni}_{40} \mathrm{P}_{20}$ alloy annealed at $873 \mathrm{~K}$ for $24 \mathrm{~h}$ in vacuum and found three phases: nickel-rich phosphide $\mathrm{Pd}_{34} \mathrm{Ni}_{45} \mathrm{P}_{21}$ (orthorhombic structure), metallic solid solution $\mathrm{Pd}_{40} \mathrm{Ni}_{59} \mathrm{P}_{1}$ (fcc structure), and palladium-rich phosphide $\mathrm{Pd}_{68} \mathrm{Ni}_{14} \mathrm{P}_{18}$ (orthorhombic structure). The fcc- $(\mathrm{Pd}, \mathrm{Ni})$ solid solution and body-centered tetragonal $\mathrm{Ni}_{3} \mathrm{P}$-like phase were also observed in a $\mathrm{Ni}_{47} \mathrm{Pd}_{36} \mathrm{P}_{17}$ ribbon glass annealed at $633 \mathrm{~K}$ for $1 \mathrm{~h}$ in argon. ${ }^{25}$ Aronin et al. ${ }^{30}$ reported tetragonal, orthorhombic, and monoclinic phases in a $\mathrm{Pd}_{40} \mathrm{Ni}_{40} \mathrm{P}_{20}$ ribbon sample annealed at $645 \mathrm{~K}$ for $200 \mathrm{~min}$ in argon.

Jing et al. ${ }^{20}$ annealed a $\mathrm{Pd}_{40} \mathrm{Ni}_{40} \mathrm{P}_{20}$ ribbon sample at 605 $\mathrm{K}$ for $50 \mathrm{~min}$ in vacuum and observed double glass transition events, indicating phase separation in their ribbon glasses. It has also been reported ${ }^{33}$ that prolonged annealing in vacuum could cause evaporation of phosphorus on the surface, so that the loss of phosphorus might accelerate the phase separation process in the system. To check whether this affects our samples, we isothermally annealed our $\mathrm{Pd}_{40} \mathrm{Ni}_{40} \mathrm{P}_{20}$ ribbon glass at $603 \mathrm{~K}$ for 2,4 , and $6 \mathrm{~h}$ in both argon (1 bar) and vacuum $\left(10^{-5}\right.$ mbar). Figures 7 and 8 show the DSC traces

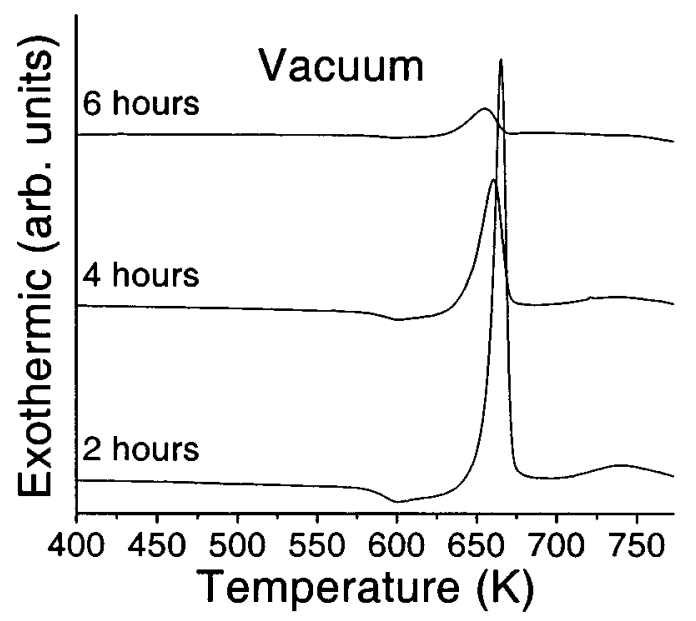

FIG. 7. The DSC traces of the $\mathrm{Pd}_{40} \mathrm{Ni}_{40} \mathrm{P}_{20}$ ribbon samples annealed at 603 $\mathrm{K}$ in vacuum for 2,4 , and $6 \mathrm{~h}$.

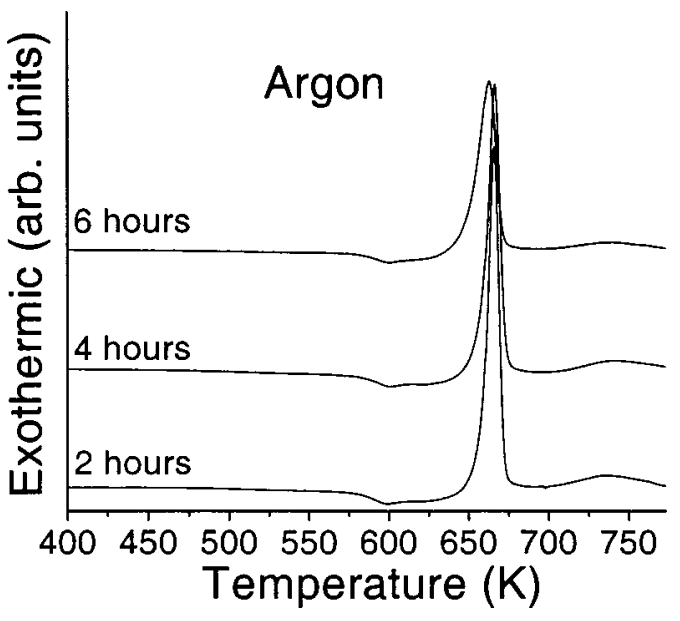

FIG. 8. The DSC traces of the $\mathrm{Pd}_{40} \mathrm{Ni}_{40} \mathrm{P}_{20}$ ribbon samples annealed at 603 $\mathrm{K}$ in $\mathrm{Ar}$ atmosphere for 2, 4, and $6 \mathrm{~h}$.

of the ribbon samples annealed in vacuum and Ar, respectively. All of the DSC traces on both of the figures exhibit only one glass transition event although the degree of crystallization in vacuum is higher than in Ar. This discrepancy between Jing et al.'s results ${ }^{20}$ and ours might be explained by different sample preparation. To further examine the influence of environment on crystallization, we performed three XRD measurements of the ribbon samples annealed at $773 \mathrm{~K}$ for $10 \mathrm{~min}$ under three pressures: (1) in vacuum $10^{-5}$ mbar; (2) in purified argon 1 bar, and (3) in a cube pressure cell used for energy-dispersive XRD (EDXRD) measurements under $6 \mathrm{kbar}$ of hydrostatic pressure (without the presence of air), as shown in Fig. 9. The XRD patterns

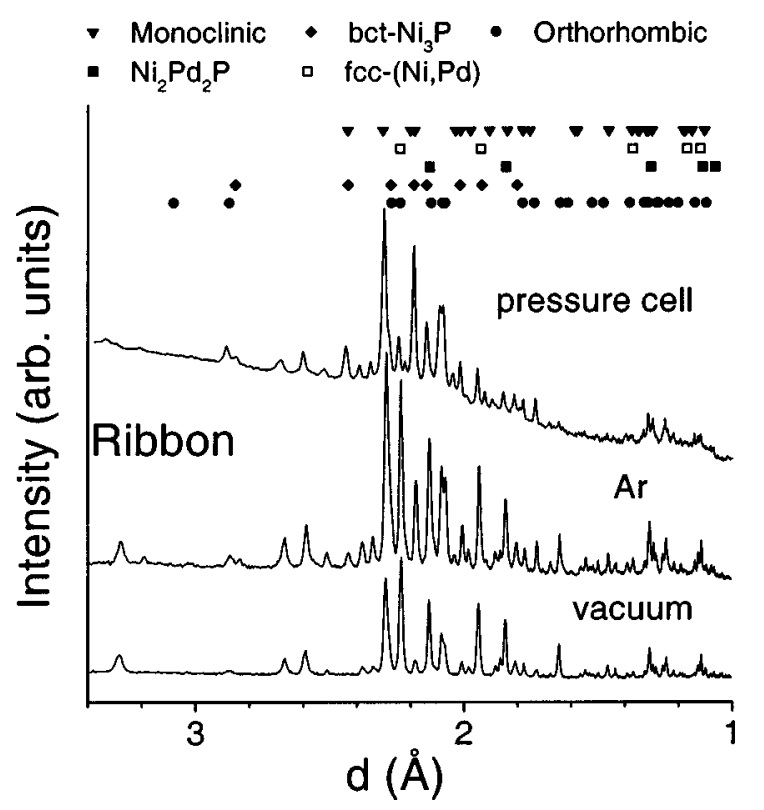

FIG. 9. X-ray diffraction patterns recorded at $295 \mathrm{~K}$ for the $\mathrm{Pd}_{40} \mathrm{Ni}_{40} \mathrm{P}_{20}$ ribbon samples annealed at $773 \mathrm{~K}$ for $10 \mathrm{~min}$ in the pressure cell used for EDXRD measurements under 6 kbar hydrostatic pressure (without presence of air); in purified argon 1 bar; and in vacuum $10^{-5}$ mbar. Due to the small amount of sample annealed in the high-pressure cell, the XRD pattern was recorded using synchrotron radiation XRD. The tiny sample was placed in an amorphous capillary, so that weak scattering of the amorphous capillary is superimposed on the XRD pattern of the sample. 


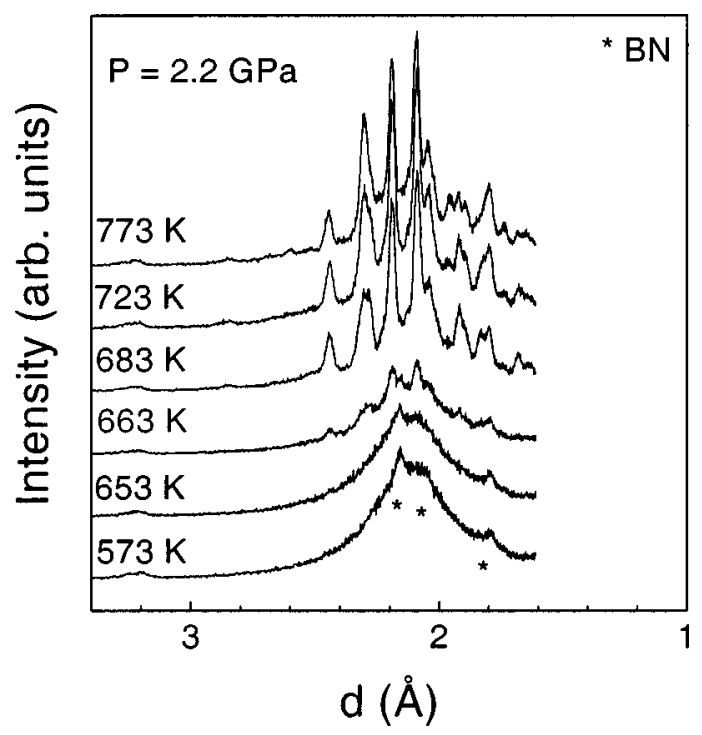

FIG. 10. In situ high-temperature and high-pressure energy-dispersive x-ray diffraction patterns for the $\mathrm{Pd}_{40} \mathrm{Ni}_{40} \mathrm{P}_{20}$ bulk glass at $2.2 \mathrm{GPa}$ and various temperatures. Some diffraction peaks of boron nitride originating from the sample holder are marked BN.

taken from samples annealed in vacuum and Ar exhibit relative higher intensive reflections of phase 5 , fcc- $(\mathrm{Ni}, \mathrm{Pd})$ solid solution, and phase $4, \mathrm{Ni}_{2} \mathrm{Pd}_{2} \mathrm{P}$, in comparison with the sample annealed in the pressure cell. The relative intensities of phase 2, bct- $\mathrm{Ni}_{3} \mathrm{P}$, and phase 3 , the orthorhombic structure, remain almost the same in all of the XRD patterns while reflections of phase 1 , the monoclinic structure, become less intense in samples annealed in Ar and vacuum. It is not unreasonable to expect that evaporation of phosphorus from the free surface in vacuum is higher than in Ar and lowest in the pressure cell. On the basis of our experiments, it might be true that phosphorus evaporation from the surface causes the monoclinic phase to become unstable so that it starts to decompose into phases 5 and 4 in the samples annealed in vacuum and Ar.

Ruitenberg et al. ${ }^{31}$ observed pressure-induced structural relaxation in a $\mathrm{Pd}_{40} \mathrm{Ni}_{40} \mathrm{P}_{20}$ ribbon glass. Structural relaxation might also affect the crystallization process of the glass. Thus, we further study the pressure effect on crystallization of the $\mathrm{Pd}_{40} \mathrm{Ni}_{40} \mathrm{P}_{20}$ bulk glass. In situ high-temperature and high-pressure EDXRD measurements of the $\mathrm{Pd}_{40} \mathrm{Ni}_{40} \mathrm{P}_{20}$ glass alloy were performed in the pressure range $0-4.2 \mathrm{GPa}$. EDXRD patterns were recorded every $10 \mathrm{~K}$ in order to observe the onset temperature of crystallization within an uncertainty of $10 \mathrm{~K}$. Figure 10 exemplifies the EDXRD patterns recorded for the sample at $2.2 \mathrm{GPa}$, and various temperatures. A broad amorphous halo, located at $d$ $\approx 2.1 \AA$, together with Bragg peaks from the BN sample holder at $d \approx 2.158,2.052$, and $1.793 \AA$, are observed in the EDXRD patterns recorded at 573 and $653 \mathrm{~K}$. Crystalline peaks appear in the pattern recorded at $663 \mathrm{~K}$. At 683, 723, and $773 \mathrm{~K}$ the sample crystallizes. The diffraction peak positions from crystallized phases are consistent with those of the phases in Figs. 5 and 6. The crystalline phases determined from the EDXRD patterns recorded are identical in the pressure range used. Figure 11 shows the crystallization

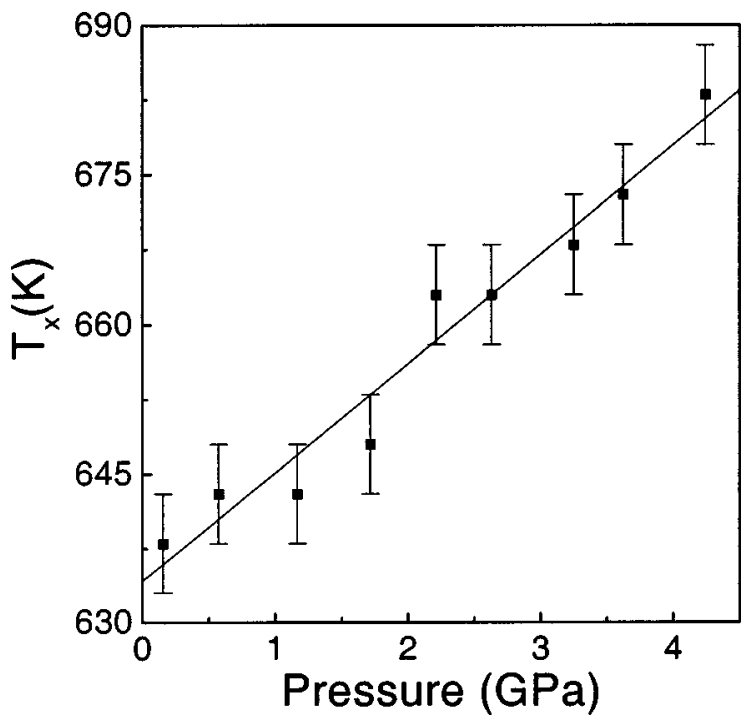

FIG. 11. Crystallization temperature $T_{x}$ of the $\mathrm{Pd}_{40} \mathrm{Ni}_{40} \mathrm{P}_{20}$ bulk glass as a function of pressure. The data were linearly fitted as the solid line.

temperature for the $\mathrm{Pd}_{40} \mathrm{Ni}_{40} \mathrm{P}_{20}$ bulk glass, which was estimated from EDXRD patterns recorded by increasing the temperature with a step size of $10 \mathrm{~K}$, as a function of pressure. It was found that pressure strongly affects the crystallization temperature of the $\mathrm{Pd}_{40} \mathrm{Ni}_{40} \mathrm{P}_{20}$ glass. The crystallization temperature increases with pressure at a rate of 11 $\mathrm{K} / \mathrm{GPa}$. This value is similar to that reported for a $\mathrm{Pd}_{40} \mathrm{Cu}_{30} \mathrm{Ni}_{10} \mathrm{P}_{20}$ bulk glass, ${ }^{49}$ and slightly smaller than the $19 \mathrm{~K} / \mathrm{GPa}$ for a $\mathrm{Zr}_{41.2} \mathrm{Ti}_{13.8} \mathrm{Cu}_{12.5} \mathrm{Ni}_{10} \mathrm{Be}_{22.5}$ bulk glass ${ }^{50} 16$ $\mathrm{K} / \mathrm{GPa}$ for a $\mathrm{Mg}_{60} \mathrm{Cu}_{30} \mathrm{Y}_{10}$ bulk glass ${ }^{51}$ in the pressure range of $0-4 \mathrm{GPa}$; and $30 \mathrm{~K} / \mathrm{GPa}$ for an $\mathrm{Fe}_{72} \mathrm{P}_{11} \mathrm{C}_{6} \mathrm{Al}_{5} \mathrm{~B}_{4} \mathrm{Ga}_{2}$ glass $^{52}$ in the pressure range of $0-2.4 \mathrm{GPa}$.

Crystallization of a metallic glass is normally regarded as a process proceeding by nucleation and subsequent growth of crystals. During the initial stage of nucleation of crystals in the glass, the effect of pressure on the crystallization kinetics is associated with the atomic diffusion process and the volume change effect. The crystallization temperature of a metallic glass may be governed by the thermodynamic potential barrier of nucleation and diffusion activation energy. According to crystallization kinetics theory, the nucleation rate $I$ can be written as $I=I_{0} / \exp \left[\left(\Delta G^{*}\right.\right.$ $\left.\left.+Q_{n}\right) / k_{B} T\right]$, where $I_{0}$ is a constant, $\Delta G^{*}$ is the free energy required to form a nucleus of the critical size, i.e., the thermodynamic potential barrier of nucleation, $Q_{n}$ is the activation energy for the transport of an atom across the interface of an embryo, and $k_{B}$ is Boltzmann's constant. The sum $\Delta G^{*}+Q_{n}$ is called the nucleation work. The difference in specific volume between crystalline and glassy $\mathrm{Pd}_{40} \mathrm{Ni}_{40} \mathrm{P}_{20}$ alloy is less than about $0.4 \%,{ }^{9,43}$ which is much smaller than previously reported values for conventional metallic glasses of about $2 \% .^{53}$ This might result in an insensitive pressure dependence of $\Delta G^{*}$ because of small $P \Delta V,{ }^{54}$ where $\Delta V$ is the difference of the molar volumes of the crystalline and glassy $\mathrm{Pd}_{40} \mathrm{Ni}_{40} \mathrm{P}_{20}$ phases. It is known that the $\mathrm{Pd}_{40} \mathrm{Ni}_{40} \mathrm{P}_{20}$ bulk glass crystallizes by a eutectic reaction, where a rearrangement of atoms is necessary. Thus, the pressure dependence of $Q_{n}$ might be the dominant factor in the nucleation 
process. In general, pressure could reduce atomic mobility, In the $\mathrm{Pd}_{40} \mathrm{Ni}_{40} \mathrm{P}_{20}$ glass, the diffusion coefficient of $\mathrm{Au}$ was reported to be reduced by external pressure. ${ }^{28}$ This means that $Q_{n}$ might increase with pressure. Hence, the nucleation work increases with pressure. Consequently, the nucleation rate decreases with pressure and an increase of the crystallization temperature is expected, as observed for the $\mathrm{Pd}_{40} \mathrm{Ni}_{40} \mathrm{P}_{20}$ bulk glass in the pressure range of $0-4.2 \mathrm{GPa}$.

\section{CONCLUSIONS}

$\mathrm{Pd}_{40} \mathrm{Ni}_{40} \mathrm{P}_{20}$ bulk and ribbon glassy alloys, prepared by a flux and water quenching and melt-spinning techniques, respectively, exhibit only one glass transition event after annealing at different temperatures in the supercooled liquid region for $30 \mathrm{~min}$. No multiglass transition events were detected in the samples annealed for long times in the supercooled liquid region in vacuum and Ar atmosphere. Crystallization is governed by nucleation and growth processes. The crystallized samples consist of at least five phases. They are monoclinic, body-centered tetragonal, orthorhombic, $\mathrm{Ni}_{2} \mathrm{Pd}_{2} \mathrm{P}$, and fcc-(Ni,Pd) solid solution phases. Decomposition of the monoclinic phase into the fcc- $(\mathrm{Ni}, \mathrm{Pd})$ solid solution and $\mathrm{Ni}_{2} \mathrm{Pd}_{2} \mathrm{P}$ phases was detected in the sample annealed in vacuum or Ar, most likely due to the evaporation of phosphorus. It was also found that the external pressure strongly enhances the crystallization temperature of the metallic glass at a rate of $11 \mathrm{~K} / \mathrm{GPa}$. The eutectic crystallization reaction mode and crystalline phases formed are unchanged in the pressure range used. The increase of the crystallization temperature with increasing pressure in the glass can be explained by the suppression of atomic mobility.

\section{ACKNOWLEDGMENTS}

We thank HASYLAB in Hamburg for use of synchrotron radiation facilities. Financial support from the Danish Technical Research Council, the Danish Natural Sciences Research Council, and the Japan Society for the Promotion of Science is gratefully acknowledged.

${ }^{1}$ A. Inoue, T. Zhang, and T. Masumoto, Mater. Trans., JIM 31, 425 (1990).

${ }^{2}$ T. Zhang, A. Inoue, and T. Masumoto, Mater. Trans., JIM 32, 1005 (1991).

${ }^{3}$ A. Peker and W. L. Johnson, Appl. Phys. Lett. 63, 2342 (1993).

${ }^{4}$ W. L. Johnson, MRS Bull. 24, 42 (1999).

${ }^{5}$ A. Inoue, Acta Mater. 48, 279 (2000)

${ }^{6}$ A. J. Drehman, A. L. Greer, and D. Turnbull, Appl. Phys. Lett. 41, 716 (1982).

${ }^{7}$ H. W. Kui, A. L. Greer, and D. Turnbull, Appl. Phys. Lett. 45, 615 (1984).

${ }^{8}$ A. J. Drehman and A. L. Greer, Acta Metall. 32, 323 (1984).

${ }^{9}$ H. S. Chen, J. T. Krause, and E. A. Sigety, J. Non-Cryst. Solids 13, 321 (1974).

${ }^{10}$ H. S. Chen, Acta Metall. 22, 1505 (1974).

${ }^{11}$ H. S. Chen, Mater. Sci. Eng. 23, 151 (1976).

${ }^{12}$ P. G. Boswell, Scr. Metall. 11, 701 (1977).

${ }^{13}$ G. Schluckebier and B. Predel, Z. Metallkd. 74, 569 (1983).

${ }^{14} \mathrm{H}$. W. Kui and D. Turnbull, Appl. Phys. Lett. 47, 796 (1985).

${ }^{15}$ M. Oehring and P. J. Haasen, J. Phys. Colloq. 47, C7-275 (1986).
${ }^{16}$ P. E. Donovan, P. V. Evans, and A. L. Greer, J. Mater. Sci. Lett. 5, 951 (1986).

${ }^{17}$ W. Wachtel, N. Willmann, and B. Predel, J. Magn. Magn. Mater. 59, 115 (1986).

${ }^{18}$ Y. Nishi and K. Mikagi, Phys. Rev. B 34, 1792 (1986).

${ }^{19}$ P. V. Evans, A. Garcia-Escorial, P. E. Donovan, and A. L. Greer, Mater. Res. Soc. Symp. Proc. 57, 239 (1987).

${ }^{20}$ J. Jing, U. Gonser, and H. G. Wagner, Z. Metallkd. 76, 767 (1987).

${ }^{21}$ A. Garcia-Escorial and A. L. Greer, J. Mater. Sci. 22, 4388 (1987).

${ }^{22}$ N. Willmann, W. Mader, E. Wachtel, and B. Predel, Phys. Status Solidi 104, 369 (1987).

${ }^{23}$ A. R. Yavari, S. Hamar-Thilbauld and H. R. Sinning, Scr. Metall. 22, 1231 (1988).

${ }^{24}$ A. R. Yavari, K. Osumura, H. Okuda, and Y. Amemia, Phys. Rev. B 37, 7759 (1988)

${ }^{25}$ M. Oehring, Z. Metallkd. 80, 1 (1989).

${ }^{26}$ Y. Xu, X. Huang, and W. Wang, Appl. Phys. Lett. 56, 1957 (1990).

${ }^{27}$ G. Wilde, G. P. Gorler, R. Willnecker, and G. Dietz, Appl. Phys. Lett. 65, 397 (1994).

${ }^{28}$ P. A. Duine, S. K. Wonnell, and J. Sietsma, Mater. Sci. Eng., A 179, 270 (1994).

${ }^{29}$ Y. He, R. B. Schwarz, and J. I. Archuleta, Appl. Phys. Lett. 69, 1861 (1996).

${ }^{30}$ A. Aronin, G. Abrosimova, I. Zver'kova, D. Lang, and R. Lück, J. NonCryst. Solids 208, 139 (1996).

${ }^{31}$ G. Ruitenberg, P. De Hey, F. Sommer, and J. Sietsma, Phys. Rev. Lett. 79, 4830 (1997).

${ }^{32}$ G. Wilde, S. G. Klose, W. Soellner, G. P. Gorler, K. Jeropoulos, R. Willnecker, and H. J. Fecht, Mater. Sci. Eng., A 226, 434 (1997).

${ }^{33}$ A. Aronin, Nanostruct. Mater. 8, 171 (1997).

${ }^{34}$ R. B. Schwarz and Y. He, Mater. Sci. Forum 235-238, 231 (1997).

${ }^{35}$ L. Sun, Q. Wu, Y. Xu, and W. Wang, Physica B 240, 205 (1997).

${ }^{36}$ C. W. Yuen, K. L. Lee, and H. W. Kui, J. Mater. Res. 12, 314 (1997).

${ }^{37}$ H. G. Read, K. Hono, A. P. Tsai, and A. Inoue, Mater. Sci. Eng., A 226, 453 (1997).

${ }^{38}$ C. W. Yuen and H. W. Kui, J. Mater. Res. 13, 3034 (1998).

${ }^{39}$ C. W. Yuen and H. W. Kui, J. Mater. Res. 13, 3043 (1998).

${ }^{40}$ M. K. Miller, D. J. Larson, R. B. Schwarz, and Y. He, Mater. Sci. Eng., A 250, 141 (1998).

${ }^{41}$ P. De Hey, J. Sietsma, and A. Van Den Beukel, Acta Mater. 46, 5873 (1998).

${ }^{42}$ K. F. Yao and H. W. Kui, Appl. Phys. Lett. 77, 2313 (2000).

${ }^{43}$ G. Wilde, G. P. Gorler, R. Willnecker, and H. J. Fecht, J. Appl. Phys. 87, 1141 (2000)

${ }^{44}$ H. W. Nagai, C. C. Leung, W. H. Guo, and H. W. Kui, J. Mater. Res. 16, 797 (2001).

${ }^{45}$ G. Wilde, Appl. Phys. Lett. 79, 1986 (2001).

${ }^{46}$ A. Inoue, N. Nishiyama, and T. Matsuda, Mater. Trans., JIM 37, 181 (1996).

${ }^{47}$ J. S. Olsen, L. Gerward, and J. Z. Jiang, J. Phys. Chem. Solids 60, 229 (1999).

${ }^{48}$ D. L. Decker, J. Appl. Phys. 42, 3239 (1971).

${ }^{49}$ J. Z. Jiang, Y. X. Zhuang, H. K. Rasmussen, N. Nishiyama, A. Inoue, and C. Lathe, Europhys. Lett. 54, 182 (2001).

${ }^{50}$ J. Z. Jiang, T. J. Zhou, H. K. Rasmussen, U. Kuhn, J. Eckert, and C. Lathe, Appl. Phys. Lett. 77, 3553 (2000).

${ }^{51}$ S. Linderoth, N. Pryds, M. Eldrup, A. S. Pedersen, M. Ohnuma, T. J. Zhou, L. Gerward, J. Z. Jiang, and C. Lathe, Mater. Res. Soc. Symp. Proc. 644, L4.1.1 (2001).

${ }^{52}$ J. Z. Jiang, J. S. Olsen, L. Gerward, S. Abdali, J. Eckert, N. Schlorke-de Boer, L. Schultz, J. Truckenbrodt, and P. X. Shi, J. Appl. Phys. 87, 2664 (2000).

${ }^{53}$ Material Science of Amorphous Alloys, edited by T. Masumoto (Ohmu, Tokyo, 1983), p. 39.

${ }^{54}$ Y. X. Zhuang, J. Z. Jiang, T. J. Zhou, H. Rasmussen, L. Gerward, M. Mezouar, W. Crichton, and A. Inoue, Appl. Phys. Lett. 77, 4133 (2000). 